\title{
NON-AGENDA
}

With the view of causing an increase to take place in the mass of national wealth, or with a view to increase of the means either of subsistence or enjoyment, without some special reason, the general rule is, that nothing ought to be done or attempted by government. The motto, or watchword of government, on these occasions, ought to be - Be quiet...Whatever measures, therefore, cannot be justified as exceptions to that rule, may be considered as non-agenda on the part of government.

- Jeremy Bentham (c.1801)

\section{Banks in the Australian Community}

\section{Kim Hawtrey}

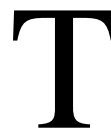
The term 'bank bashing' refers to 'unjustified and unfair criticism of banks' (Valentine, Ford and Copp, 2003:89) and has become a regular occurrence in Australia and overseas. Critics such as Hand (2001) in Australia and Coggins (1998) in the United Kingdom have argued that financial deregulation has failed consumers and have called for an end to the deregulated approach to the banking industry on the grounds that banks act like a cartel. This school of thought has enjoyed widespread support outside academia, including from certain arms of government (New South Wales Department of Fair Trading, 1999), some consulting firms (Deloitte Research, 2000) and the media (Sampson, 2000).

Such anti-bank opinion is likely to have real economic effects. There is evidence that sustained media criticism of corporations leads to increased instability in the institutions concerned and their senior management (Farrell and Whidbee, 2002). Criticism of banks has given rise to the 'community banking' movement in Australia and other countries such as the United States, with mixed implications for the integrity of the banking system (Yeager, 2004). Calls are currently being made in the political sphere for stronger direct government regulation of banks (Australian Labor Party, 2004). This could possibly involve measures such as imposing fee ceilings, mandating branch quotas or legislating for universal free bank accounts. Such re-regulation of the industry would almost certainly have negative implications for allocative efficiency and global competitiveness of banks (Sturm and Williams, 2004).

The purpose of this paper is to assess certain criticisms made against Australian banks, using a comprehensive set of industry data brought together in a unified manner, in three main areas: affordability, access and social obligations.

Kim Hawtrey is Senior Lecturer Department of Economics Macquarie University. 
First, the claim that the monetary cost of banking has increased is found to be false when all forms of revenue are taken into account. Second, the charge that banks have reduced points of banking access is evaluated using measures based on Bank for International Settlements (BIS) benchmarks. Third, the claim that banks are failing to return 'social capital' to the community is contrasted with their contribution data. The conclusions have significant implications for future community debate and government policy toward the industry.

\section{Affordability of Banking}

An important first step in measuring 'affordability' is to employ a comprehensive definition. The overall remuneration customers are paying to banks, relative to the volume of services rendered, is the most comprehensive measure of affordability. Such a global measure involves aggregation of customer outlays to compensate the industry for services rendered. There are two main costs to the consumer:

- $\quad$ interest margin — the net cost to the community from paying and receiving interest; and

- non interest margin — the net cost to the community from paying and receiving fees.

These costs need to be considered together, not in isolation as often occurs in public debate. It is also important to use appropriate scaling. For instance, assessments of 'raw dollar' payments to banks by the community are meaningless if no attempt is made to relate the payments to the steady increase in the use of banks' services. Also, it is useful to benchmark the community's banking overheads against that in other countries.

When both interest and non-interest margins are taken into account, aggregate community remuneration to banks has unambiguously declined. Table 1 shows total remuneration by the rest of the economy to the Australian banking sector in interest plus fees, scaled against the growth of bank balance sheets. Relative to the growth in services received, as measured by balance sheet growth, there has been no net increase in fees paid. At the same time the net interest margin paid to banks by the community has trended down. The growth in fees has been in line with growth in domestic balance sheet assets, and the reduction in interest margins has more than offset the increase in fee income. This is broadly consistent with evidence in the literature from other countries post-deregulation, postglobalisation (Maudos and Fernández, 2004; Saunders and Schumacher, 2000).

The constancy of fees may suggest banks have been over-charging in latter years, because a relatively constant fee to assets ratio could be taken to imply either that no economies of scale are present in the provision of banking services, or that the banks are not passing on such economies to customers. Yet it also needs to be remembered that fees started from an artificially low base at the beginning of the 1990s. Under the old regime of cross-subsidisation and nontransparent account-keeping fees, consumers paid the fee component implicitly in 
the form of higher interest margins. In the 1990s, banks switched to transparent recovery of account-keeping costs (allowing them to reduce interest margins) and began to provide explicit statements of fees charged to consumers. Starting from a historically low explicit fees base, sharp increases in the ratio of fees to assets over the decade as banks played 'catch up' would not have been surprising. The fact that a sharp increase did not occur suggests that that banks may have limited the impact by passing on significant cost savings to customers.

Table 1: Major Banks, Net Interest and Fee Income

\begin{tabular}{l|ccc}
\hline Year & $\begin{array}{c}\text { Domestic net income to } \\
\text { average domestic assets ratio }\end{array}$ & $\begin{array}{c}\text { Domestic bank fees to } \\
\text { average domestic assets ratio }\end{array}$ & Total \\
\hline & \multicolumn{3}{c}{ per cent } \\
1997 & 2.94 & 0.99 & 3.93 \\
1998 & 2.52 & 1.05 & 3.57 \\
1999 & 2.33 & 1.06 & 3.39 \\
2000 & 2.26 & 1.02 & 3.28 \\
2001 & 2.08 & 0.95 & 3.04 \\
2002 & 2.04 & 0.97 & 3.01 \\
2003 & 1.96 & 0.99 & 2.95 \\
2004 & 1.96 & $0.59^{\mathrm{a}}$ & 2.55 \\
\hline
\end{tabular}

Note: ${ }^{a}$ the sharp fall from 0.99 to 0.59 in the fees to assets ratio in 2004 largely reflects a drop in merchant service fees as a result of the reforms to credit card payments.

Source: Reserve Bank of Australia (2004; 2005).

A further objection may concern technological change. Extensive technological advance in the delivery of banking services has generated productivity improvements (Rushdi and Tennant, 2003) that might have been expected to produce a commensurate decline in the fee to assets ratio. Once again, the 'standing start' factor is important to the story. At the beginning of the 1990s, the use of technology in banks was not extensive, but this changed rapidly with substantial technology investment in the 1990s. That investment was expensive not just for normal business reasons, but also because of the particular historical phase the decade represented. It was the decade of change from traditional paperbased banking to electronic banking. This investment had to be paid for and while part of the explanation is the closure of bank branches (see next section), another part is that to pay for the technology upgrade, banks sought to recoup costs through fees. In other words, while it is true that technology has brought with it productivity gains in service delivery, by the same token it carried a huge up-front cost for the banks. The cost was incurred up-front, swamping to some degree the productivity gains which will be more fully evident in future years.

Have all sections of the community been equally affected, or have some borne more of the fee burden than others? There is evidence that ordinary customers on the whole have experienced faster increases in fees than big 
business. Over the period 1996 to 2004 inclusive, the average annual growth rate of bank fees levied on households was 15 per cent (Reserve Bank of Australia, 2005), compared with 11 per cent for business. At the start of the above period, households accounted for 29 per cent of total fee revenue and business for 71 per cent. By 2004, the household share had risen to 38 per cent and the business share had declined to 62 per cent. The fee burden has therefore tilted in a direction unfavourable to households, especially in the product areas of credit cards (29 per cent average annual growth) and personal loans (25 per cent). Clearly, this is an area of the affordability debate where criticism of the banking industry has a good deal of support from the data, and which the industry may need to address.

By the same token, households have been major beneficiaries of the overall improvement in banking affordability since the end of cross-subsidisation and the accompanying fall in retail loan interest margins. The margin today between official rates and home loans is almost 2.5 percentage points narrower than a decade ago (Reserve Bank of Australia, 2005:Tables F1, F5). The reduced margin translates into substantial savings for home buyers, amounting to thousands of dollars on their mortgage each year. This may be illustrated using Australian Bureau of Statistics (2004) figures which show that the average value of owneroccupied housing loans taken out in mid-2004 was $\$ 196,952$. Thus, the squeeze on margins as a result of competition over the past ten years saves the average home buyer more than $\$ 92$ a week.

A comparison of the Australian banking sector with its overseas counterparts provides a horizontal perspective on affordability. It shows that, in terms of affordability relative to asset size, banks in Australia rank about the middle of an international peer group. Table 2 summarises the data on net interest margin (NIM) and non-interest margin (NOM) as a ratio to total assets for Australia and fifteen other countries. The database used is Bank Profitability: Financial Statements of Banks, a publication of the Organisation for Economic Cooperation and Development (OECD). The data provide comprehensive annual information on the financial statements of all banks in OECD member countries, where the definition of 'banks' includes all institutions conducting ordinary banking business, such as taking deposits from the public at large and making loans for a wide variety of purposes. The framework used for presenting the statistics is that recommended by the OECD's Task Force on Bank Profitability. Australian banks' fee income (NOM) is not high by world standards, ranked $7^{\text {th }}$ out of sixteen countries. The highest earners of fee income are Finland (3.1 per cent) and the US (2.6 per cent). The reliance of UK banks on fees (1.4 per cent) is approximately around the same level as that of Australian banks (1.5 per cent).

Perhaps the ultimate test of affordability is to look at the revealed preference of consumers when it comes to the choice of whether to use banks at all. A genuine fee-free alternative to account banking exists for every customer, namely do-it-yourself bookkeeping and currency-only transactions. Despite the existence of this no-fees cash alternative, more than 17 million Australians 'vote with their feet' and choose to employ the account services of their bank over the cheaper (at least in simple monetary terms) alternative of making payments in notes and coin 
with self-managed record keeping. This revealed preference for account banking by customers gives genuine indication of the economic value the community places on the services banks provide, and its willingness to pay, despite the availability of a less expensive alternative (in terms of monetary cost). A bank account also confers other benefits to personal and business users, including better security, regular interest, access to electronic funds transfer networks, and account statements for accurate record-keeping.

Table 2: Banking Affordability by Country

\begin{tabular}{l|cc}
\hline Country & NIM/total assets ratio & NOM/total assets ratio \\
\hline & 1.4 & 1.5 \\
\hline Australia & 1.0 & 0.9 \\
Belgium & 2.1 & 2.2 \\
Canada & 1.9 & 1.3 \\
Denmark & 1.7 & 3.1 \\
Finland & 1.0 & 1.7 \\
France & 1.3 & 0.7 \\
Germany & 2.6 & 1.1 \\
Italy & 1.5 & 1.2 \\
Netherlands & 2.0 & 1.2 \\
New Zealand & 2.3 & 0.8 \\
Norway & 2.4 & 0.9 \\
Spain & 1.1 & 1.5 \\
Sweden & 1.2 & 1.7 \\
Switzerland & 1.8 & 1.4 \\
UK & 3.4 & 2.6 \\
US & 1.8 & 1.5 \\
\hline Average & & \\
\hline
\end{tabular}

Note: Net interest income margin (NIM) is the margin earned by banks from traditional 'intermediation' activities and is calculated as the difference between interest received (IR) by banks on assets and interest paid (IP) on liabilities, as a ratio to total assets (TA): NIM $=(\mathrm{IR}-\mathrm{IP}) / \mathrm{TA}$. The non-interest income margin $(\mathrm{NOM})$ is the difference between non-interest income received (OR) and non-interest income paid (OP), expressed as a ratio to total assets: $\mathrm{NOM}=(\mathrm{OR}-\mathrm{OP}) / \mathrm{TA}$. Net noninterest income incorporates fees receivable and payable, commissions receivable and payable, net profit or loss on securities trading, and other miscellaneous noninterest items.

Source: OECD (2003). 


\section{Accessibility of Banking}

If 'accessibility' is conceived of solely in terms of branch teller service, then it is undeniable that Australian banks have reduced the number of traditional branches and the community has experienced a reduction in branch-style accessibility.

Notwithstanding this, however, several countervailing observations need to be made. First, the data show that the downtrend in branch numbers has stabilised in the past two years (Table 3). After the lengthy period of rationalisation that lasted about ten years, since 2002 the number of branches has begun to increase again, marking a reversal of the trend. Indeed, at least one player (Bendigo Bank) has announced a new strategy that involves intentionally increasing its branch numbers.

Table 3: Points of Public Banking Access

\begin{tabular}{l|cccccc}
\hline Year & Branches & giroPost & ATMs & EFTPOS & Total & $\begin{array}{c}\text { Total- } \\
\text { excluding } \\
\text { EFTPOS }\end{array}$ \\
\hline 1990 & 6,921 & $\mathrm{Na}$ & 4,636 & 15,514 & 27,071 & 11,557 \\
1991 & 6,917 & $\mathrm{Na}$ & 4,956 & 22,752 & 34,625 & 11,873 \\
1992 & 6,920 & $\mathrm{Na}$ & 5,314 & 26,260 & 38,494 & 12,234 \\
1993 & 7,064 & $\mathrm{Na}$ & 5,483 & 30,486 & 43,033 & 12,547 \\
1994 & 6,747 & $\mathrm{Na}$ & 5,910 & 51,707 & 64,364 & 12,657 \\
1995 & 6,655 & $\mathrm{Na}$ & 6,422 & 88,082 & 101,159 & 13,077 \\
1996 & 6,508 & 2,557 & 7,465 & 123,984 & 140,514 & 16,530 \\
1997 & 6,121 & 2,627 & 8,670 & 177,766 & 195,184 & 17,418 \\
1998 & 5,615 & 2,720 & 9,472 & 230,573 & 248,380 & 17,807 \\
1999 & 5,358 & 2,724 & 10,089 & 278,238 & 296,409 & 18,171 \\
2000 & 5,003 & 2,814 & 11,819 & 333,739 & 353,375 & 19,636 \\
2001 & 4,789 & 2,821 & 13,289 & 375,883 & 396,782 & 20,899 \\
2002 & 4,843 & 2,962 & 16,398 & 415,167 & 439,370 & 24,203 \\
2003 & 4,858 & 2,990 & 20,339 & 433,640 & 461,827 & 28,187 \\
2004 & 3,040 & 4,888 & 21,550 & 465,757 & 495,243 & 29,486 \\
\hline
\end{tabular}

Source: RBA, Bulletin, Table C.5. Figures as at June.

Second, any reasonable measure of access to banking today needs to extend beyond branches and include the new forms of service delivery in all their variety. Less than two decades ago, banking services were operated using passbooks and offered only at branches between 10am and 3pm, Monday to Friday — it was a 'horse-and-buggy' system known for its Friday afternoon rush for weekend cash. Today, bank accounts are effectively accessible 24-hours a day seven days a week and customers need not even leave home to do their banking. More than 90 per cent of transactions are today conducted outside bank branches. As Table 3 shows, the growth in non-branch points of access has been rapid. A large 
proportion of the savings that banks made by closing branches were reinvested in alternative modes of delivery. Customers today have access to over 20,000 automatic teller machines (ATMs), a figure that has quadrupled since 1990, and more than 433,000 electronic funds transfer at point-of-sale terminals (EFTPOS) compared with only 15,000 in 1990.

Figure 1: Points of Presence: International Comparison

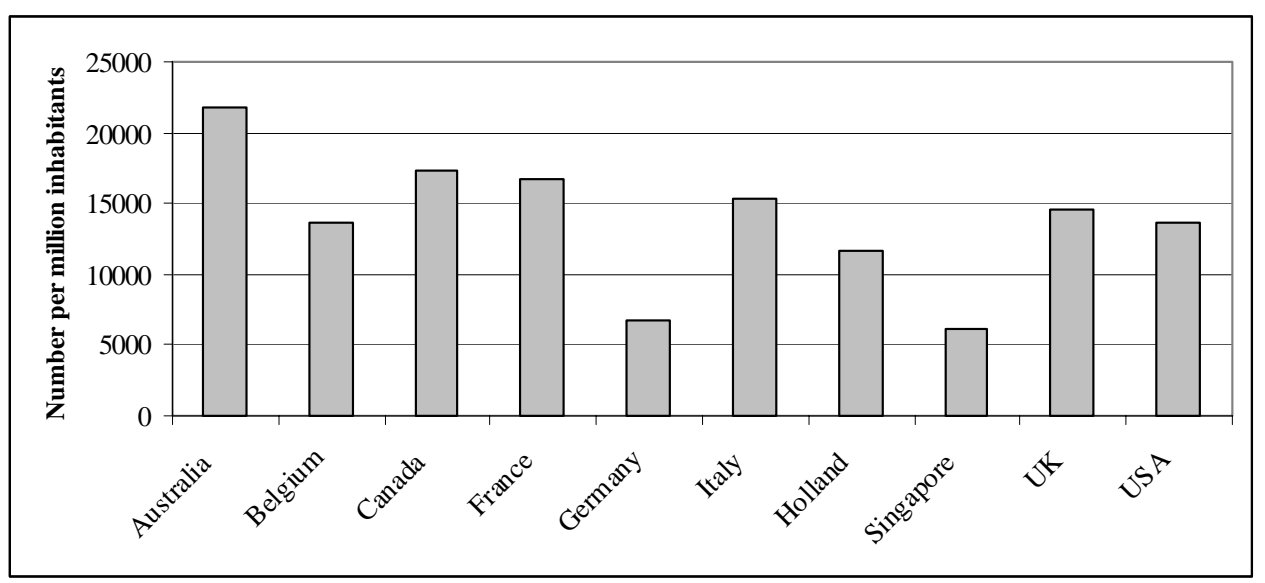

Note: Figures for 2002; total includes branches, ATMs and EFTPOS.

Source: Bank for International Settlements;

This principle of recognising mixed modes of delivery in a modernising industry is now incorporated by BIS in its international benchmarking of points of access to banking. The BIS statistical measure includes branches, ATMs, EFTPOS, and giroPost. These represent physical supplier-installed points where customers can conduct the majority of everyday banking services such as withdrawing cash or making payments. By the BIS definition, compared with other countries Australia is a world leader in points of access (Figure 1). The international average is 12,700 points of presence per million inhabitants. Australia has 21,800 points.

An important facet of the accessibility debate concerns rural and remote locations. Here, the evidence is surprising: proportionally, banks are underrepresented in cities and over-represented in remote and very remote locations. On a per capita basis, the banking industry's service network exceeds the population base (6.0 per cent of banking points of presence serve just 2.9 per cent of the population in remote areas). The geographic distribution of branch services across rural Australia matches closely where people live, and frequently exceeds the population base in proportional terms (see Table 4).

In 2002 a Parliamentary Inquiry (Chapman, 2002) was conducted into the level of banking services in rural and remote Australia. A study for that Inquiry (Bamford, 2002) compared the geographic spread of banks with other common services: police, schools, hospitals and pharmacies. It found that the physical 
presence of banks in remote communities is closely similar to that of schools, and better than pharmacies (see Table 5). As essential services, only schools and police have a greater presence than banks in remote and very remote locations. Further, through a rural postcode survey the Parliamentary Inquiry identified that there are fewer than 15 towns across Australia with no face-to-face banking service, and even in most of these cases there is either giroPost or a bank agency within 20 kilometres (Chapman, 2002).

Table 4: Geographic Spread of Face-to-Face Services

\begin{tabular}{l|rrrcc}
\hline \multicolumn{1}{c|}{ ARIA Category } & Branch & Other & $\begin{array}{c}\text { Total excl. } \\
\text { giroPost }\end{array}$ & $\begin{array}{r}\text { per cent } \\
\text { of Total }\end{array}$ & $\begin{array}{c}\text { Population } \\
\text { reach (\%) }\end{array}$ \\
\hline Highly accessible & 3,324 & 1,597 & 4,921 & 63.5 & 65.9 \\
Accessible & 833 & 667 & 1,500 & 19.3 & 20.6 \\
ModeratelyAccessible & 455 & 358 & 813 & 10.4 & 10.6 \\
Remote & 144 & 109 & 253 & 3.3 & 1.8 \\
VeryRemote & 102 & 108 & 210 & 2.7 & 1.1 \\
Unclassified & & 35 & 35 & 0.9 & 0.0 \\
Total & 4,858 & 2,874 & 7,732 & 100.0 & 100.0 \\
\hline
\end{tabular}

Note: The ARIA remoteness index is used, developed by the National Centre for Social Applications of Geographic Information Systems, for the Department of Health and Ageing (see http://www.health.gov.au/ari/aria.htm).

Source: ARIA, ABS Population Census 2001, APRA Points of Presence Survey 2003.

Table 5: Points of Presence of Selected Services by ARIA Category

\begin{tabular}{l|ccccc}
\hline & Police & Schools & $\begin{array}{c}\text { Banking/ } \\
\text { Financial }\end{array}$ & Hospitals & Pharmacies \\
\hline Highly Accessible & 360 & 1,574 & 1,510 & 135 & 1,224 \\
Accessible & 410 & 1,187 & 817 & 207 & 436 \\
Moderately Accessible & 498 & 971 & 762 & 227 & 270 \\
Remote & 145 & 258 & 188 & 75 & 50 \\
Very Remote & 133 & 137 & 103 & 60 & 16 \\
\hline
\end{tabular}

Source: GISCA, 2002 ARIA; 2001 Telstra White Pages; DETYA 1999; ABA, 2001; Commonwealth Department of Health and Aged Care, 2001; Pharmacy Guild of Australia, 2002.

The accessibility of banking in remote areas goes well beyond even the numbers above - customers can also use thousands of private (non-installation) points of access such as personal computers, fixed telephones and mobile phones as their primary banking 'location'. The percentage of Australian households with access to a computer at home has increased steadily from 44 per cent in 1998 to 61 per cent in 2002. Internet access at home has increased strongly, rising from 16 per cent in 1998 to 46 per cent in 2002 (ABS, 2003). 
In summary, Australia does not suffer to the same degree the problems found in other countries relating to a high recorded incidence of 'financial exclusion'. Recent research by the Financial Services Authority (FSA) in the UK, for instance, estimated that around 1.5 million households (7.0 per cent) in Britain have no basic bank or building society account whatsoever (FSA, 2000). A further 4.4 million (20 per cent) have only very limited access to financial services. The FSA found that the extent of financial exclusion in the UK is high - up to 9 per cent of adults have no bank or building society account of any kind, one third of households have no savings or investment products, 27 per cent of employees have no occupational or private pension, and up to a quarter of households have no home contents insurance. While directly parallel statistics are not available, the available evidence points to a much more inclusive banking sector in Australia.

\section{The Contribution of Banks to 'Social Capital'}

The concept of social capital or community service obligations is gaining clearer definition in the recent literature. Donaldson and Dunfee (1999) argue (in their influential book Ties that Bind) that implicit understandings or 'contracts' exist that bind industries, companies, and economic systems into communities. Using Integrative Social Contracts Theory they demonstrate how the theory can be applied to particular social questions currently being asked of the financial services industry, such as how should banking institutions interlock with broader community objectives.

A starting point for assessing the social contribution of Australian banks to the community is the extent to which they provide 'basic account' banking to the needy. A recognised definition (FSA, 2003) is an account that offers a minimum of six free transactions per month, and carries no account-keeping fees. Using this definition, the scale and scope of provision of basic bank accounts by the industry in Australia is very extensive. At a minimum, the banking industry already automatically offers basic accounts to around six out of every ten Australians. The population of Australia may be subdivided into three groups: children aged up to 18 years; concession card holders (described below); and other adults. These three cohorts provide a useful framework for assessing basic banking in Australia today, and give a good indication of its extensive availability. The two concessionary cohorts - 5.9 million cardholders and 5.4 million children immediately qualify for and enjoy automatic access to free or low-cost accounts. In many instances, such customers receive basic banking services free of charge. Concession cardholders (29.9 per cent; Department of Education, Science and Training, 2003: Table 19) together with children aged eighteen or under (26.9 per cent; Department of Family and Community Services, 2004) account for 57 per cent of the Australian population of 20 million, or about six out of every ten persons.

The largest group of concession cardholders is older Australians. Banks operate pensioner deeming accounts for such cardholders, with no account- 
keeping fee, between six and unlimited free transactions per month, BPAY facility, access to ATMs and EFTPOS, and in virtually all cases, a cheque facility. The Department of Family and Community Services (FACS) publishes and regularly updates an independent survey on its website of financial institutions offering deeming accounts. According to FACS, an account is a 'deeming account' if the bank pays interest rates generally based on the current social security deeming rates. In its bulletin of 2 July 2004, FACS confirms the widespread availability of these accounts, which 'are offered by the four major banks, other banks, and a large number of credit unions and building societies'.

The extent of basic banking extends well beyond concession cardholders and children, however. Within the 43 per cent labelled 'Other Adults' are many additional customers who also can access free or low-cost bank accounts. Within the general customer category, banks offer tailored basic products for approved customers from a diverse range of groups such as, small business, Christmas Clubs, farmers, mortgagors, not-for-profit organisations and others. Data obtained from market survey firm Cannex shows there are currently almost 100 products that fit the 'basic account' description, including many that can be utilised by customers who belong to the Other Adults segment. A key finding from the survey is that all retail banks operating in Australia offer at least one account that has no account keeping fee and at least six free transactions per month.

Some have called for a single industry-wide mandated generic bank account that low-income earners could access. While all mainstream retail Australian banks offer a form of 'basic bank account', it is not currently possible to institute a uniform industry-wide product. The reason is the existence of a legal impediment that prevents banks from agreeing together over product design. The Trade Practices Act 1974 disallows competitors agreeing on the pricing of products, which includes setting a price at zero and features of basic bank accounts without authorisation from the competition regulator. Indeed, a proposal for an agreement between ten banks in 2002 to provide an industry basic bank account was denied authorisation by the Australian Competition and Consumer Commission on the grounds it would not 'expand consumer choice'.

Provision of basic bank accounts is considered the most important aspect of banks' contribution to 'social capital', however it is not the only factor. A further part is their extensive philanthropy. Based on information in annual reports, banks donate over $\$ 90$ million a year to charitable and community causes, involving gifts to worthy causes, projects and sponsorships to support particular local organisations (examples currently include junior cricket, Opera Australia, community cinema, heritage buildings, zoos, theatres, orchestras, and country arts festivals) and environmental projects to improve conservation and sustainability, such as the Banksia Awards, WIRES and the Holsworth Wildlife Research Fund. A number of banks are signatories to the UN Environment Program for banks. In-kind support relates to time donated by bank staff on worthy local projects such wrapping Christmas presents for welfare agencies, marshalling and assisting with registration at a variety of events, or manning telephones and counting cash at 
fund appeals. Banks also contribute in kind by making available their branch facilities for collecting donations without charge.

An often overlooked aspect of contributing to 'social capital' is the maintenance of a reliable and well-managed banking system. This is vital to the safekeeping of the savings of ordinary depositors. Because of the nature of banking, there is a constant trade-off between risk and return - between safety and profitability. In this regard, Australian depositors, entrusting their money to banks, can have good reason for confidence. Australian banks maintain higherthan-average levels of safe assets, compared with banks elsewhere in the world. International evidence shows that Australian banks currently have the highest capitalisation in the OECD, a factor that is not cost-free to shareholders who must forego potentially higher returns on loans in order to allow the banks hold high reserves. Based on a survey of thirty countries, some of which are shown in Figure 2 Australia leads in holdings of Capital Plus Reserves, expressed as a ratio to total balance sheet assets, with 11.5 per cent. The comparable figure for the USA is 9.1 per cent, and for the UK is 5.1 per cent. Alongside this, International ratings of Australian banks' governance are impressive. Governance Metrics International (www.gmiratings.com), a US-based independent ratings agency, rates 1600 companies from fifteen countries using such criteria as board accountability, disclosure and corporate behaviour. Australia's major banks are rated 'Above-Average' relative to the global cohort.

\section{Figure 2: Bank Capital and Reserves (ratio to balance sheet)}

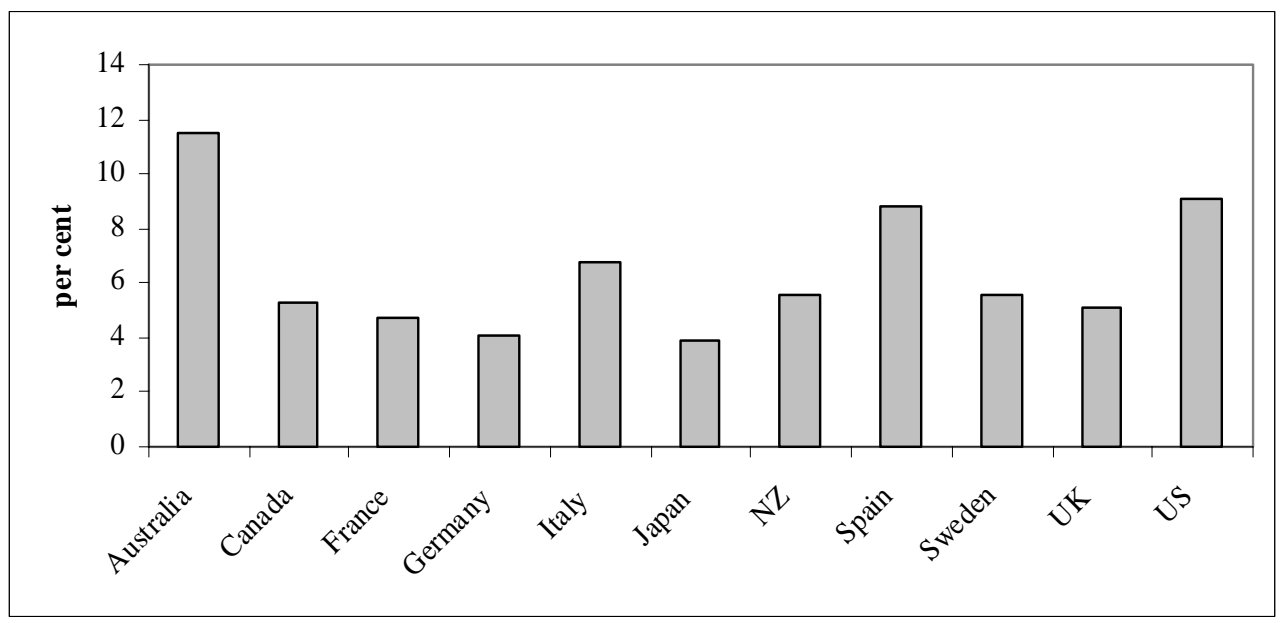

Source: OECD, Bank Profitability: Financial Statements of Banks, 2003. Figures are for 2001 reporting year. 


\section{Conclusion}

This paper has evaluated three common criticisms of Australian banks in the light of evidence from industry data. First, the paper evaluated the claim that the cost of banking to the average consumer has increased such that bank revenues are at record levels, and found the reverse to be true. When all forms of revenue are taken into account, banking in Australia has never been more affordable to the community as whole than it is today. Improved affordability has been marked for household customers and Australian bank fees and profits are not high by world standards.

Second, the paper assessed the claim that banks have unduly reduced their branch network and found that as measured by Bank for International Settlements criteria, accessibility to Australian bank services in non-traditional formats has expanded significantly and is the highest in the world. The decline in branch numbers has been reversed and representation in remote regions is proportionally greater than in the cities.

Third, the paper assessed the assertion that, as an 'essential service', banks are failing in social obligations to the community. It has been argued that, on reasonable criteria, the Australian industry substantially meets its social obligations and returns significant 'social capital' to the community. Banks' services are supplied free of charge or at low cost to over 60 per cent of customers. Around 100 basic bank accounts are offered by the industry, including to groups as diverse as farmers and home buyers. Each year, community organisations receive over $\$ 90$ million dollars of direct support in various forms, from banks and Australian banks' level of safe assets is high by world standards.

These conclusions have significant implications for future government policy, especially for evaluating current interventionist proposals such as imposing fee ceilings, mandating branch quotas or legislating for universal free bank accounts. To the extent such policy proposals are based on the three criticisms evaluated in this paper, they are misguided or at the very least require fresh justification. The evidence suggests that direct government sanctions on banks are not required to achieve improved economic outcomes for consumers or to induce satisfactory corporate citizenship on the part of banks.

\section{References}

Australian Bureau of Statistics (2004), Housing Finance, Australia, Cat. No. 5609.0, Canberra, April.

Australian Bureau of Statistics (2003), Household use of Information Technology, 2001-02, Cat. No.8146.0, Canberra.

Australian Labor Party (2004), Banking Policy, Policy Statement, Canberra, 20 June.

Bamford, E. (2002), Background Paper for the Parliamentary Inquiry into the Level of Banking and Finance Services in Rural and Remote Australia, National Centre for Social Applications of GIS, University of Adelaide, South Australia, October. 
Bank for International Settlements (BIS), Payments System Statistics, available at Reserve Bank of Australia website (www.rba.gov.au).

Chapman, G. (2002), Report into the Level of Banking and Finance Services in Rural and Remote Australia, Joint Committee on Corporations and Financial Services, Senate, Australian Parliament, Canberra.

Coggins, B. (1998), Does Financial Deregulation Work? A Critique of Free Market Approaches, New Directions in Modern Economics Series, Edward Elgar, UK.

Deloitte Research, (2000), Myths vs Reality in Financial Services: What your Customers Really Want, October, Sydney.

Department of Education, Science and Training (2003), Students 2003: Selected Higher Education Statistics, Canberra.

Department of Family and Community Services, (2004), Annual Report 2003-04, Canberra.

Donaldson, T. and T. Dunfee, (1999), Ties that Bind: A Social Contracts Approach to Business Ethics, Harvard University Business School Press, Cambridge, MA.

Farrell, K. and Whidbee, D. (2002), 'Monitoring by the Financial Press and Forced CEO Turnover', Journal of Banking and Finance 26(12):2249-76.

Financial Services Authority (2000), In or Out? Financial Exclusion: A Literature and Research Review, Consumer Research 3, July, UK.

Financial Services Authority (2003), No Bank account? Why it Could Pay you to Have One, May, UK.

Hand, G. (2001), Naked Among Cannibals: What Really Happens Inside Australian Banks, Allen \& Unwin, Sydney.

Hawtrey, K. (2003), 'Money and Banking', Chapter 8 in P. Lewis, A.Garnett, K. Hawtrey and M. Treadgold, Issues, Indicators and Ideas: A Guide to the Australian Economy, $3^{\text {rd }}$ edition, Pearson Australia.

Human Rights and Equal Opportunity Commission (2000), Accessibility of Electronic Commerce and New Service and Information Technologies for Older Australians and People with a Disability, Report, Canberra.

Maudos, J. and J. Fernández, (2004), 'Factors Explaining the Interest Margin in the Banking Sectors of the European Union', Journal of Banking and Finance 28(9):2259-81.

New South Wales Department of Fair Trading (1999), Banks and Community Obligations, Report, Sydney, June.

Organisation for Economic Cooperation and Development (OECD), Bank Profitability: Financial Statements of Banks, Paris, 2003.

Reserve Bank of Australia (2004), 'Bank Fees in Australia', Reserve Bank of Australia Bulletin, May.

Reserve Bank of Australia (2005), 'Banking Fees in Australia', Reserve Bank of Australia Bulletin, May. 
Rushdi, M. and J. Tenant (2004), 'Profitability of Australian Banks: 1985-2001, Agenda 10(3):229-43.

Sampson, A. (2000) 'Banks Show Little Interest in Savings Small Fry’, Sydney Morning Herald, 8 April.

Saunders, A. and L. Schumacher (2000), 'The Determinants of Bank Interest Rate Margins: An International Study’, Journal of International Money and Finance 19:81332.

Sturm, J. and B. Williams (2004), 'Foreign Bank Entry, Deregulation and Bank Efficiency: Lessons from the Australian Experience', Journal of Banking and Finance, 28(9):1775-99.

Valentine, T., G. Ford and R. Copp (2003), Financial Markets and Institutions in Australia, Prentice Hall, Sydney.

Yeager, T. (2004), 'The Demise of Community Banks? Local Economic Shocks Are not to Blame', Journal of Banking and Finance 28(9):2135-53.

The author wishes to thank the Editor and anonymous referees for helpful comments on an earlier draft. 